\title{
PENGUATAN KELEMBAGAAN KOPERASI PRODUSEN KOPI JAVA PREANGER DALAM UPAYA MENINGKATKAN KINERJA BISNIS DAN PENDAPATAN PETANI KOPI
}

\author{
Djuwendah, E. Karyani, T. Syamsiah N. dan H. Hapsari \\ Staf Pengajar Prodi Agribisnis, Fakultas Pertanian UNPAD, \\ E-mail: endah.djuwendah@unpad.ac.id
}

\begin{abstract}
ABSTRAK. Mitra IbM adalah Koperasi Produsen Kopi Margamulya dan Kelompok Tani Utami yang mengusahakan kopi arabika Java Preanger di Desa Margamulya Kecamatan Pangalengan Bandung. Masalah produktivitas usaha tani kopi masih rendah, yakni kurang dari 1 ton/ha karena masih tingginya serangan hama dan penyakit tanaman serta masih diusahakan secara semi organik. Koperasi Margamulya belum dapat memenuhi permintaan pasar dari segi kualitas dan kuantitas serta belum memiliki pembukuan usaha yang baik. Masalah yang dialami mitra Kelompok Tani Utama di antaranya produktifitas usaha tani kopi yang masih rendah. Metode yang digunakan adalah pemberdayaan secara partisipatif, yang meliputi pelatihan, pendampingan, monitoring evaluasi, bantuan bahan, dan alat. Materi pelatihan yang diberikan kepada Kelompok Tani Utama meliputi pengenalan hama dan penyakit tanaman kopi, pembuatan pestisida dan herbisida organik, serta pembukuan usaha tani. Materi pelatihan yang diberikan kepada Koperasi Margamulya berupa pelatihan manajemen koperasi, pencatatan, dan pembukuan usaha koperasi. Bantuan bahan dan alat diberikan kepada Koperasi Margamulya dalam bentuk alat tulis dan white board, serta alat penyeduh kopi. Evaluasi dilakukan setelah pelatihan, selama pendampingan, dan menjelang kegiatan IbM berakhir. Hasil yang dicapai menunjukkan sekitar $75 \%$ petani dapat melakukan teknik pencatatan usahatani dan menganalisis keuntungan usaha taninya. Sikap petani lebih baik terhadap koperasi dan mengelola usaha tani kopi secara organik dengan lebih baik.Petani lebih intensif merawat kebun, mengurangi pestisida kimia secara berangsur dan mengganti dengan teknik pestisida dan herbisida organik. Pengurus Koperasi Margamulya mampu menyusun pencatatan dan pembukuan usaha koperasi serta mengelola ussaha koperasi dengan lebih baik.
\end{abstract}

Kata kunci: koperasi, manajemen, petani kopi arabika

\section{PENDAHULUAN}

Kopi merupakan salah satu komoditas unggulan perkebunan yang bernilai ekonomis tinggi bagi Indonesia. Jawa Barat memiliki potensi pengembangan kopi yang besar dan memiliki kopi khas Jawa Barat yang dikenal dengan nama kopi Java Preanger. Kecamatan Pangalengan Kabupaten Bandung memiliki beberapa kawasan pegunungan sebagai pusat pengembangan kopi arabika di antaranya Gunung Tilu, Gunung Patuha, dan Gunung Malabar. Kopi dan kopi arabika Java Preanger yang dihasilkan oleh petani kopi di kawasan Gunung Tilu Pangalengan, memenurut hasil penelitian Balai penelitian kokako Jember tahun 2012, kawasan Gunung Tilu memiliki potensi tanaman kopi bermutu tinggi. Kopi yang dihasilkan adalah jenis specialty karena memperoleh nilai uji citarasa 84,08 dengan kategori excellent.

Guna mewadahi agribisnis kopi arabika Java Preanger di Desa Margamulya sudah dibentuk Koperasi produsen kopi Margamulya pada tahun 2014. Proses bisnis yang sudah dijalankan oleh koperasi itu di antaranya sebagai pengumpul/penghimpun kopi dari petani, menyediakan fasilitas pengolahan kopi, dan memasarkan olahan kopi dalam bentuk green bean coffee. Konsumen kopi produksi Koperasi Margamulya sudah cukup banyak di antaranya PT Taman Delta Indonesia. Permintaan Toko kopi Aroma dan Glory morning café sampai saat ini masih belum terpenuhi.

Koperasi produsen kopi adalah koperasi yang menghimpun buah kopi baik dari anggota maupun bukan anggota untuk diolah dan dipasarkan serta menyediakan sarana produksi yang diperlukan oleh para anggota koperasi. Koperasi produsen kopi Margamulya dibentuk pada 17 Februari 2014. Kegiatan agribisnis kopi di Koperasi Produsen Kopi Margamulya adalah pengolahan kopi mulai dari cherry (petik merah) sampai dengan green bean sehingga membantu meningkatkan mutu hasil panen kopi anggotanya karena telah menerapkan SOP (Standard Operasional Procedure) dan telah mendapat UTZ Certified; dengan prinsip budidaya kopi arabika yang tidak menggunakan pupuk anorganik kecuali untuk penanaman awal saja (Ima Marlina, 2014).

Bisnis usaha Kopi koperasi Margamulya berawal dari usaha tani kopi yang dilakukan oleh anggota koperasi dan anggota kelompok tani kopi. Belum semua petani kopi anggota koperasi Margamulya yang melaksanakan usaha tani kopi sesuai dengan sertifikat UTZ. Serangan hama dan penyakit tanaman kopi masih terjadi dan menyebabkan menurunnya produksi. Produktivitas kopi arabika petani anggota koperasi Margamulya berkisar berkisar 600-900 $\mathrm{kg} /$ tahun, lebih rendah dibandingkan dengan produktivitas kopi nasional $1.500 \mathrm{~kg} / \mathrm{ha} / \mathrm{tahun}$ (Nur dan Soenarjo, 1990). Dengan demikian, pendapatan petani juga masih rendah. Upaya peningkatan pendapatan dapat dilakukan melalui dua cara, yaitu peningkatan produktivitas dan peningkatan mutu hasil dengan mengembangkan kopi arabika organik. Permintaan kopi organik dunia akhir-akhir ini meningkat karena meningkatnya permintaan komoditas yang bebas residu pestisida dan teknologi ramah lingkungan. Permintaan produk organik berkembang pesat, suatu ketika produk tidak organik akan sulit dipasarkan.

Belum semua anggota koperasi aktif menjual kopi ke koperasi. Pengurus Koperasi Margamulya kesulitan dalam memilah hasil kopi dari anggota koperasi dan 
bukan anggota. Pengurus Koperasi tidak memiliki waktu dan kapasitas membuat laporan keuangan koperasi secara baik. Dengan tidak adanya laporan keuangan yang baik akan menyulitkan untuk menilai kinerja bisnis koperasi yang sedang berjalan. Laporan keuangan juga diperlukan untuk pengajuan kredit ke lembaga pembiayaan apabila Koperasi Margamulya ingin memperluas skala usahanya.

Adapun tujuan dari Kegiatan IbM ini addalah (1) memberikan pengetahuan dan keterampilan petani tentang cara budidaya kopi arabika secara organik, (2) memberikan pengetahuan dan ketarampilan kepada petani kopi dalam pengelolaan hama dan penyakit tanaman kopi secara terpadu menggunakan bahan nabati, (3) memberikan pengetahuan dan keterampilan cara kepada pengurus koperasi dalam pencatatan usaha dan pembukuan koperasi secara baik, (4) meningkan kesadaran anggota koperasi untuk berpatisipasi aktif dalam kegiatan koperasi, dan (5) memberikan pengetahuan dan keterampilan kepada pengurus Koperasi Margamulya dalam pencatatan usaha dan pembuatan laporan keuangan koperasi.

Hasil penelitian Ima marlina (2014) menemukan bahwa Koperasi Margamulya memiliki peluang besar dalam bisnis usahanya karena kopi yang dihasilkan termasuk kopi khusus dengan pasar yang sudah tersedia. Saat ini Koperasi membutuhkan stategi Growth and Build. Namun dalam operasionanya koperasi mengalami kesulitan dalam pengelolaan kopi dan pengedalian mutu terutama dari hasil pembelian kopi bukan anggota yang belum menerapkan pertanian organik sesuai dengan sertifikasi UTZ. Pencatatan persediaan barang dan keuangan di Koperasi Produsen Kopi Margamulya masih sederhana, belum menerapkan manajemen persediaan dan keuangan yang baik sehingga hal itu dapat menjadi kendala dalam pengembangan bisnis koperasi di masa mendatang.

Sebagai upaya mewujudkan aspirasi petani dan koperasi kopi arabika Java Preanger di Desa Margamulya Pangalengan Bandung, Tim IbM Fakultas Pertanian merasa perlu melaksanakan progam pengabdian pada mitra guna membatu kegiatan pengembangan kopi arabika Java Preanger dan pada akhirnya dapat meningkatkan pendapatan petani kopi di daerah itu.

\section{METODE}

Kegiatan Ipteks bagi Masyarakat(IbM) dilaksanakan pada bulan Mei hingga November 2016, ditujukan untuk meningkatkan kinerja bisnis koperasi dan pendapatan petani kopi. Metode yang digunakan dalam kegiatan ini adalah metode pelatihan yang berbentuk penyuluhan, pendampingan, dan bantuan material (fasilitasi) dengan melibatkan mitra secara aktif dalam perencanaan, pelaksanaan, dan evaluasi sesuai kebutuhannya dan mampu mandiri setelah kegiatan IbM berakhir.

Perumusan masalah dan penggalian solusi alternatifnya dilakukan secara FGD (Focus Group Discussion).
Pelatihan dilakukan secara berkelompok dengan metode ceramah, diskusi, simulasi, dan demontrasi. Peserta berperan aktif mencoba mempraktekkan materi yang sudah disampaikan. Kegiatan itu melibatkan dosen dan mahasiswa dari prodi Agribisnis dan Agroteknologi Fakultas Pertanian Unpad.

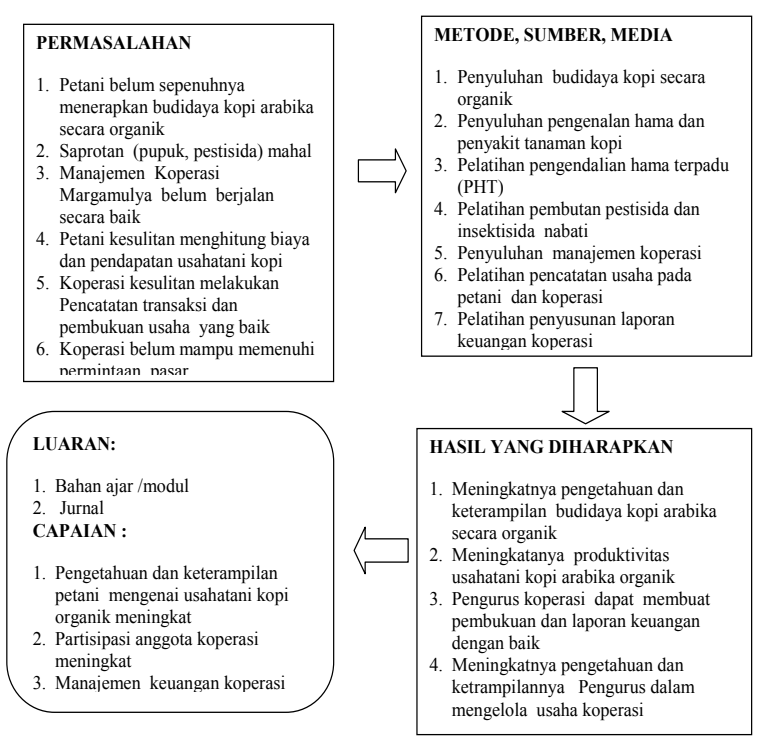

\section{Gambar 1. Kerangka Penyelesaian Masalah}

Kesesuaian materi penyuluhan dan pelatihan diukur berdasarkan persepsi mitra terhadap masalah yang dihadapi dan solusi yang ditawarkan. Monitoring, evaluasi, pendampingan, dan fasilitasi dilakukan dalam rangka mengontrol keberlanjutan usaha.

Menurut Totok dan Soebianto (2013), keberhasilan kegiatan diukur berdasarkan (1) tingkat partisipasi peserta dalam keseluruhan kegiatan; (2) perubahan perilaku yang meliputi penegetahuan, sikap dan keterampilan;(3) kualitas produk yang dihasilkan; dan (4) kesesuai materi pelatihan dengan kebutuhan Mitra. Perubahan pengetahuan diukur dari pretest dan posttest. Sikap dilihat dari semangat mengikuti seluruh rangkaian kegiatan IbM. Keterampilan dilihat dari kemampuan membuat pestisida dan herbisida nabati, kemampuan pencatatan dan menghitung biaya dan pendapatan usaha tani kopi, praktek pengendalian hama terpadu. Kesesuaian materi pelatihan diukur berdasarkan persepsi mitra terhadap masalah yang dihadapi dan solusi yang ditawarkan.

\section{HASIL DAN PEMBAHASAN}

\section{Pelatihan budidaya Kopi Arabika secara Organik}

Budidaya kopi organik berbeda dengan budidya kopi non organik. Kopi organik merupakan kopi yang diproduksi dengan berlandaskan pada pertanian yang berkelanjutan. Sistem usaha tani organik dibudidayakan pada lingkungan yang bebas bahan kimia, dan dibudidayakan secara organik. Budidaya kopi organic adalah menanam kopi yang didasarkan pada kaidah-kaidah pertanian organik yang ramah lingkungan dengan memi- 
nimalkan penggunaan input produksi kimiawi seperti pupuk dan obat-obatan kimiawi (pestisida, herbisida kimia). Meningkatnya kesadaran konsumen akan perlunya kesehatan dan kepedulian terhadap keamanan lingkungan yang mendorong permintaan kopi yang bebas residu bahan kimia berbahaya (kopi organik) semakin tinggi sehingga harga jualnya lebih tinggi daripada kopi bukan organik. Tingginya harga jual kopi organik dan meningkatnya harga input sarana produksi seperti pupuk dan pesdtisida kimiawi ternyata mendorong minat petani untuk beralih dari budidaya kopi konvensional ke budidaya kopi secara organik.

Penanganan pascapanen kopi organik memerlukan kecermatan agar memenuhi standard mutu yang diinginkan (Puslit Koka, 2004). Beberapa tahapan dalam budidaya kopi arabika organik adalah sebagai berikut.

\section{a. Menentukan Lokasi yang Ideal}

Lokasi ideal untuk penanaman kopi organik adalah lahan yang belum pernah terkontaminasi oleh penggunaan pupuk dan pestisida kimia maupun obatobatan pemberantas hama dan penyakit. Kondisi agroklimat yang baik untuk budidaya kopi arabika organik adalah ketinggian 700-1500 m dpl dengan kisaran optimum 900-1100 m dpl; memiliki batas yang tegas antara musim kering dan penghujan atau Iklim C - D menurut Schmidt dan Fergusson dengan curah hujan 1.000-2.000 mm/tahun dengan 3-5 bulan kering; tanah dengan tekstur geluh pasiran dan kaya bahan organik, terutama pada daerah dekat permukaan tanah; dan tersedianya sarana pengairan dan atau pohon pelindung dan sifat kimia tanah menghendaki pH agak masam yaitu 5,5-6,5(litbang \deptan,2014).

\section{b. Pemakaian Bibit Tanaman Kopi yang Organik}

Bibit-bibit kopi yang dipakai harus berasal dari pembibitan secara organik dan sebaiknya dipilih varietas yang memiliki ketahanan tinggi terhadap hama dan penyakit tanaman. Karena cukup sulit menemukan bibit kopi organik di pasar bibit, sebaiknya menumbuhkan benih kopi sendiri agar didapatkan bibit tanaman kopi organik yang bersifat murni.

\section{c. Penggunaan Pupuk Kandang dan Pupuk Kompos}

Selama pemeliharaan tanaman kopi digunakan pupuk yang didapatkan dari alam seperti pupuk kandang dari kotoran hewan dan pupuk kompos dari sampah tumbuhan. Peningkatan pemberian gizi bisa dilakukan dengan memberikan mineral-mineral alami seperti batu fosfat, kapur dolomit, dan sebagainya. Sebelum ditaburkan ke lahan kopi, pupuk organik wajib melalui proses dekomposisi terlebih dahulu.

\section{Pelatihan Pengedalian Hama dan Penyakit Tanaman Kopi secara Terpadu}

Produktivitas tanaman kopi anggota Kelompok Tani Utama dan anggota Koperasi Margamulya realtif masih di bawah produktivitas kopi arabika secara nasional yaitu sebesar $1.200 \mathrm{~kg} / \mathrm{ha}$. Berbagai kendala teknis yang dialami petani di lapangan di antaranya terjadinya serangan hama dan penyakit tanaman yang megakibatkan turunnya produksi sekitar 20 s.d $40 \%$.

Berdasarkan hasil wawancara dengan peserta dan observasi lapangan ditetapkanlah hama dan penyakit yang paling sering menyerang tanaman kopi di Kelompok Tani Utama, yakni hama penggerak buah kopi (Hypothenemus hampei ferr (PBKo)), kutu hijau (coccus viridis) dan penyakit karat daun kopi (hemiliea vastratrix). Hama pengerek menyerang buah kopi biasanya terlihat adanya lubang di bagian buah kopi yang berakibat buah tidak berkembang, mengalami pembusukan, dan jatuh.

\section{Pengendalian Hama Terpadu}

Pengendalian Hama secara Terpadu (PHT) dijadikan indikator dalam standarisasi ekspor kopi internasional, baik di pasar Eropa maupun pasar Amerika Serikat. Tujuan PHT adalah (1) meminimalisir kerusakan tanaman yang diakibatkan oleh hama dan penyakit tanaman; (2) meminimalisir toksisitas yang diakibatkan oleh penggunaan pestisida terhadap kesehatan manusia, lingkungan dan produk pertanian; dan (3) mengurangi biaya produksi terhadap perlindungan tanaman(Siska Rasiska, 2013).

Petani telah mengenal beberapa cara pengendalian hama yaitu secara mekanik, kultur teknis, secara fisik, dan pengendalian secara hayati. Pengendalian hama secara hayati merupakan teknik penggendalian dengan menggunakan musuh alami. Beberapa cara mudah yang dapat dilakukan adalah dengan (1) mempertahankan keberadaan musuh alami (konservasi musuh alami) dan (2) menambah jumlah musuh alami. Konservasi musuh alami dapat dilakukan dengan cara (1) tidak menggunakan pestisida; (2) menanam tanaman berbunga; dan (3) melestarikan tanaman liar sebagai tanaman inang predator.

Menurut Astuti (2011) terdapat beberapa cara pengedalian hama terpadu pada tanaman kopi. PHT untuk PBKo dan kutu hijau di antaranya untuk pengendalian hayati menggunakan beberapa musuh alami PBKo di ataranya jamur Beauveria bassiana, tawon, semut, capung, dan laba-laba. Melesatarikan kumbang hel dan larvanya sebagai musuh alami kutu hijau, pengendalian mekanis dengan cara memetik buah yang terserang PBKo, dimusnahkan dengan cara direbus atau dipendam. Menghilangkan sarang semut rang-rang dan penambahan tanaman pelindung untuk mengendalikan kutu hijau dan penggunaan insektisida dan pestisida nabati.

\section{Pelatihan Pembuatan Pestisida dan Herbisida Nabati}

Pestisida nabati adalah pestisida yang bahan aktifnya berasal dari tanaman atau tumbuhan dan bahan orbanik lainnya yang berkasiat mengendalikan serangan hama dan penyakit pada tanaman (Badan Litbang Perta-nian, 2016). Permintaan produk perkebunan yang 
bebas dari residu bahan kimia berbahaya akhir-akhir ini semakin meningkat, termasuk di dalamnya bebas dari residu pestisida kimia. Mengingat dampak negatif yang ditimbulkan dari penggunaan pestisida sintetik, perlu dicari komponen pengendalian hama terpadu (PHT) yang dirasa aman, efektif, dan murah untuk menyusun pengelolaan OPT pada tanaman perkebunan.

Jenis tanaman yang dapat digunakan untuk menanggulangi hama pengerek tanaman kopi antara lain sereh wangi (Cympogon nardus) dan saliera (Lantena camaraLinn Lantadene), daun sirsak (Annona muricata), daun nimba (Azadirachta indica), daun babadotan (Ageratum conyzoides), dan bawang putih (Allium sativum). Kandungan kimiawi sereh wangi adalah senyawa dipentene, sitronela, geraniol, stral, nerol, mirsea, dan farsenol methyl. Kandungan kimia yang dimiliki saliera berupa minyak atsiri A, B-Coryophille acid, r-cynaene, Humule, A-pinene. B-Lantanolic acid dan g- terpidene.Tata cara pembuatan pestisida dan insektisida nabati adalah sebagai berikut.

1. Pestisida nabati dari daun sereh wangi dan saliera

- tumbuk halus 50-100 gram sereh wangi dan saliera atau merebusnya;

- ambil ekstrat ditambahkan sedikit air lalu diperas;

- diamkan larutan hingga 3-5 hari; dan

- encerkan larutan , maka larutan siap dipakai.

2. Pestisida daun nimba (Azadirachta indica A. Juss)

- tumbuk halus 200-300 gram biji nimba: rendam dengan 10 liter air semalam, aduk rata dan saring, siap disemprotkan ke tanaman; dan

- tumbuk halus $1 \mathrm{~kg}$ daun nimba kering bisa juga dengan daun segar rendam dalam 10 liter air semalam, aduk rata, saring, dan siap untuk disemprotkan ke tanaman.

3. Pestisida Nabati daun sirsak (Annona muricata L)

- tumbuk halus 50-100 lembar daun sirsak;

- rendam dalam 5 liter air+15 grm detergen,aduk rata dan diamkan semalaman;

- saring dengan kain halus; dan

- di cairkan kembali 1 liter larutan pestisida dengan 10-15 liter air dan semprotkan.

4. Pestisida tembakau (Nicotiana tabacum)

- rajang 250 grm daun tembakau dan rendam dalam 8 liter air selama semalam;

- ambil daun tebakau dan tambahan 2 sendok teh detergen kedalam larutan hasil rendaman; dan

- aduk larutan secara merata kemudian saring dan siap disemprotkan ke tanaman.

5. Pestisida bawang putih (Allium sativum)

- gerus /Parut 100 grm bawang putih campur dengan 0,5 liter air 10 grm detergen, dan 2 sendok teh minyak tanah;

- diamkan selama 24 jam, kemudian saring dengan kain halus; dan

- encerkan larutan hasil penyaringan 20 kali volumenya dan semprotkan ke tanaman.
6. Pestisida daun ramayana (Cassia spectabillis)

- $2 \mathrm{~kg}$ daun ramayana muda dicuci kemudian dirajang lalu direndam dalam 201 air;

- larutan pestisida nabati dibiarkan (diinkubasikan) selama 4 hari, ditutup;

- larutan diaduk setiap hari untuk menghindari penguapan gas;

- setelah 4 hari, larutan hasil perendaman disaring dengan menggunakan kain halus;

- larutan pestisida nabati $30 \mathrm{ml}$ diaplikasikan dengan cara dicampur dengan satu liter air dan diberi deterjen dengan 0,5 gram deterjen per liter larutan;

- penyemprotan perlakuan menggunakan alat semprot knapsack sprayer punggung;

- penyemprotan larutan diarahkan pada buah-buah kopi pada cabang primer dan sedikit diarahkan pada daun kopi; dan

- gunakan sebanyak empat kali dengan interval satu bulan, cukup efektif dalam mengendalikan hama penggerek buah kopi (PBKo, Hypothenemus hampei) dan kutu putih (Planococcus citri).

1. Pelatihan untuk Meningkatkan Pengetahuan dan Keterampilan Pengurus Koperasi dalam Meningkatkan kinerja Bisnis

Setelah resmi berdiri sekitar 3 tahun, Koperasi Margamulya telah memiliki sarana dan prasarana yang cukup baik berupa bangunan kantor koperasi yang dilengkapi dengan pabrik pengolahan kopi , lantai jemur kopi, mesin pengolahan kopi (pulper, huller, qwasher dan grande) yang merupakan hibah dari Provinsi Jawa Barat. Kopi yang dihasilkan dijual kepada pihak Taman Delta Indonesia (TDI), toko Aroma, dan Glory Morning Cafe.

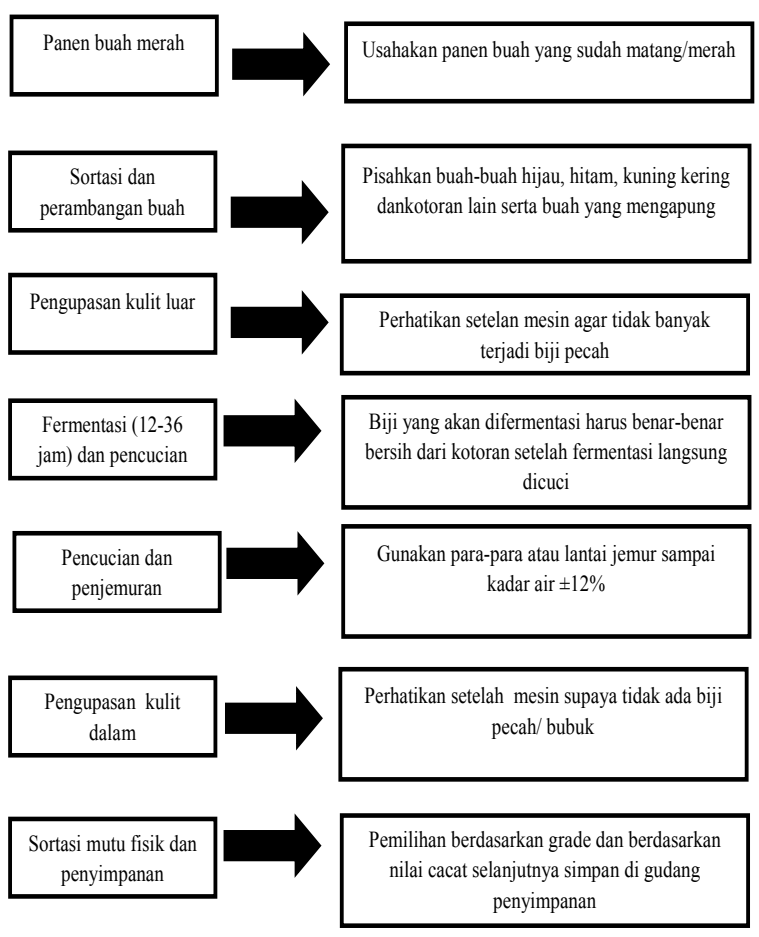

Gambar 2 . SOP Pengolahan Kopi Arabika di Koperasi Margamulya 
Saat ini koperasi merintis menjual kopi bubuk dengan nama "Kopi Java Preanger Gunung Tilu", walaupun jumlahnya terbatas karena hanya dipasarkan bagi para pengunjung yang datang ke Koperasi Margamulya. Semakin berkembangya koperasi memerlukan pengelolaan yang lebih baik agar tujuan koperrasi tecapai dengan efisien. Oleh karena itu, guna meningkatkan kemampuan pengurus dalam manajemen pengelolaan bisnis koperasi, dilakukan pelatihan manajemen pengelolaan koperasi dan pencatatan usaha serta pembuatan laporan keuangan koperasi. Untuk anggota koperasi diberikan motivasi tentang pentingnya partisipasi angota dalam kegiatan bisnis koperasi dengan cara meningkatkan volume penjualan kopi ke koperasi dan ikut membayar simpanan wajib koperasi.

Pelaksanaan progam IbM ini berjalan baik. Keberhasilan progam dapat dilihat dari partisipasi mitra selama kegiatan berjalan. Partisipasi mitra dalam bentuk (1) kehadiran; (2) menyediakan tempat pertemuan (saung meeting); (3) membantu perijinan dan administrasi yang diperlukan; (5) sarana pertemuan (tikar, instalasi listrik dan air); dan (6) bahan dan alat untuk pelatihan seperti contoh hama kopi, batang tanaman yang terserang hama, bahanbahan untuk pestisida, dan herbisida alami. Perubahan pengetahuan dan sikap dari mitra dapat dilihat dari tolok ukur meningkatnya hasil posttest pengetahuan dan sikap perserta terhadap materi yang diberikan. Rata-rata 85 persen peserta menguasi materi yang diberikan. Sekitar $80 \%$ petani dapat melakukan teknik pencatatan usaha tani dan menganalisis keuntungan usaha taninya. Sikap petani lebih baik terhadap koperasi dan bertekad untuk menerapkan usaha tani kopi secara organik. Namun, baru sekitar 65 persen yang telah menerapkannya. Hal itu disebabkan karena untuk menerapkan pertanian organik yang benar memerlukan pengondisian lahan pertanian yang relatif lama, sementara lahan usaha tani komoditas lain yang berada di sekitarnya masih dikelola secara konvensional. Pembuatan pestisida dan insektisida nabati murah, namun diperlukan kesabaan, keuletan dan ketekunan yang sangat tinggi dan pengaruhnya dalam pengendalian hama penyakit tanaman tidak secepat menggunakan bahan kimiawi. Di sisi lain, sebagian besar petani kopi mengalami keterbatasan dalam alokasi waktu karena mereka juga merangkap sebgai petani hortikultura sehingga perawatan kopi belum dilakukan secara intensif.

Sekitar 84 persen materi tentang teknis pencatatan dan pembukuan usaha dapat dipahami oleh pengurus koperasi. Semua pengurus bertekad untuk menerapkan sistem pembukuan usaha dengan baik dan bertekad untuk memperbaiki manajemen usaha koperasi.

Faktor-faktor pendukung keberhasilan pelaksanaan kegiatan adalah sebagai berikut.

1. Kegiatan ini dirancang sesuai kebutuhan mitra, sehingga partisipasi mitra baik, terlihat dari peran serta dalam semua kegiatan.

2. Kegiatan ini secara tidak langsung didukung oleh DinasPertanian Kehutanan yang memberikan bantuan bibit kopi arabika kepada para petani.

3. Solidaritas Tim Pelaksana dalam mengerjakan semua aspek kegiatan.

4. Dukungan dana yang memadai dan lancar dari Ditlitabmas, Ditjen Dikti, Kementrian Pendidikan dan Kebudayaan

Faktor yang menjadi penghambat adalah sebagai berikut.

1. Curahan waktu petani mitra untuk mengelola kebun kopi dan ternak sapi cukup besar sehingga waktu yang tersedia untuk mengikuti penyuluhan dan pelatihan agak terbatas.

2. Tempat Pelaksanaan Kegiatan di Koperasi Margamulya realtif cukup jauh dari rumah para petani sehingga untuk mengganti biaya transportasi Tim IbM memberikan dana transportasi kepada para peserta pelatihan dan penyuluhan.

3. Sulitnya menentukan waktu pertemuan/penyuluhan dengan petani, karena di lapangan sedang berlangsung panen dan proses pengolahan kopi di koperasi.

4. Sulitnya merubah perilaku sebagian petani yang tidak mau sulit meluangkan waktu dan tenaga.

Kegiatan Pengabdian pada Masyarakat yang telah dilaksanakan diharapkan dapat memberikan manfaat sebagai berikut.

1. Meningkatkan pengetahuan dan keterampilan petani dalam menerapkan teknis budidaya kopi arabika organik sehingga dapat meningkatkan daya saing produk dan menurunkan biaya produksi karena menggunakan pestisida dan herbisida nabati serta mengunakan pupuk organik.

2. Meningkatakan pengetahuan dan ketampilan pengurus Koperasi Margamulya dalam melakukan pembukuan dan laporan keuangan usaha koperasi dengan baik sehingga dapat meningkatkan kinerja bisnis koperasi.

3. Meningkatakan pengetahuan dan perubahan sikap anggota koperasi tentang hak dan kewajibannya untuk bersama-sama koperasi meningkatkan produktifitas usaha dan pendapatanya.

4. Dosen dapat menerapkan hasil penelitian untuk memberdayakan masyarakat dan memanfaatkan lokasi mitra sebagai laboratorium sosial.

\section{SIMPULAN}

Berdasarkan hasil kegiatan IbM "Penguatan Kelembagaan Koperasi Produsen Kopi Java Preanger dalam Upaya Meningkatkan Kinerja Bisnis dan Pendapatan Petani Kopi", dapat disimpulkan bahwa kegiatan itu berguna dalam upaya untuk meningkatkan pengetahuan dan keterampilan petani dalam budidaya kopi arabika secara organik, meningkatkan pengetahuan dan keterampilan petani dalam pengendalian hama secara terpadu dengan menggunakan pestisida dan herbisidanabati, meningkatkan 
pengetahuan dan keterampilan petani dalam menganalisis biaya dan penerimaan usaha taninya. Dengan kegiatan itu kinerja bisnis koperasi juga meningkat melalui perbaikan pencatatan dan pengelolaan pembukuan usaha koperasi sertta mengikatnya kemampuan manajerial dari pengurus koperasi. Guna lebih meningkatkan semangat berusaha tani dan nilai tambah kopi bagi petani, direkomendasikan hal berikut ini.

1. Perlu adanya pelatihan dan pendampingan petani kopi dalam penanganan pascapanen dan pengupasan kulit buah kopi sehingga petani mendapat nilai tambah karena menjual dalam bentuk berasan harganya lebih tinggi.

2. Perlu adanya pendampingan manajemen keuangan pada koperasi guna meningkatkan kinerja keuangannya sehingga mempermudah akses kepada lembaga keuangan.

3. Pengembangan kopi arabika Java Preanger sebaiknya terintegrasi dengan program PHBM dari dinas Kehutanan dengan menggiatkan tanaman pekarangan, penghijauan lahan-lahan kosong, dan agroforestry.

\section{UCAPAN TERIMAKASIH}

Kegiatan Pengabdian kepada Masyarakat ini terlaksana dengan baik berkat bantuan dan dukungan dari berbagai pihak. Oleh karenaitu penghargaan danucapan terimakasih sebesar-besarnya diberikan kepada Dit.Litabmas - Ditjen Dikti yang telah mendukung dana Program Ipteks bagi Masyarakat (IbM) tahun anggaran 2016, DRPM Unpad, ketua Koperasi Margamulya, ketua kelompoktani Utama dan seluruh peserta pelatihan, dosen dan mahasiswa dari Klinik Tanaman Prodi Agroteknologi dan Prodi Agribisnis Unpad yang berkenan menjadi narasumber dalam pelatihan ini.

\section{DAFTAR PUSTAKA}

Anonimus, 2013.Budidaya Tanaman Kopi Arabika Ramah Lingkungan Berbasis Teknologi Bio $\sim \boldsymbol{F O B}$; http:// www.meori-agro.co.id/artikel/biofob/197-bio-fob. html.

Anonimus. 2014. "Pengkajian Komponen Teknologi Pertanian Menunjang Sistem Usaha Tani Kopi Arabika Organik dalam Perspektif Agribisnis"; www.sulsel.litbang.deptan.go.id.

Astuti, U. P., Tri, W., Bunaiyah, H. 2013. Petunjuk Teknis Pembuatan Pestisida Nabati. Balai Pengkajian Teknologi Pertanian (BPTP) Bengkulu.

Astuti, Yuni.2011. "Perlindungan Tanaman Kopi”. Http:// Ditjenbun.deptan .go.id/perlindungan/indesx.php. htm. Diakses pada 10/4/2016.

http://ntb.litbang.pertanian.go.id/ind/index . php?option $=$ com_content $\&$ view $=$ article $\&$ diaksesid=919:pembuatan-pestisida-nabati\&catid $=49$ :info-teknologi\&Itemid $=81$. Diakses 10/4/2016.

Mardikanto, Totok dan Poerwoko Soebianto. 2012. Pemberdayaan Masyarakat. Penerbit Alfabeta. Bandung.

Marlina, Ima, 2014. "Analisis Kesiapan dan Strategi Pengembangan Bisnis koperasi Produsen Kopi Margamulya". Skripsi pada Prodi Agribisnis Faperta UNPAD.

Rasiska, Sisca. 2013. "Pengendalian Hama Terpadu pada Tanaman Kopi: Lebah Madu Membantu Penyerbukan Bunga Kopi”. Modul IbM Kelompok Petani Kopi Manglayang. LPPM-UNPAD. Bandung.

Sudarmo, S. 2005. Pestisida nabati. Jakarta: Penerbit Kanisius. 